\title{
Nicotine Receptor Inactivation Decreases Sensitivity to Cocaine
}

\author{
Venetia Zachariou, Ph.D., Barbara J. Caldarone, Ph.D., Ariel Weathers-Lowin, \\ Tony P. George, M.D., John D. Elsworth, Ph.D., Robert H. Roth, Ph.D., \\ Jean-Pierre Changeux, Ph.D., and Marina R. Picciotto, Ph.D.
}

The reinforcing properties of nicotine and psychomotor stimulants are thought to be mediated through the mesolimbic dopamine (DA) system. This study investigates the role of high affinity nicotinic acetylcholine receptors ( $\mathrm{nAChRs)}$ in cocaine place preference and examines some neurochemical changes in the mesolimbic DA system that might account for the interaction between nicotine and cocaine. $5 \mathrm{mg} / \mathrm{kg}$ is the lowest dose of cocaine able to condition a place preference in $\mathrm{C} 57 \mathrm{Bl} / 6$ mice. Co-treatment with the nicotinic antagonist mecamylamine $(1.0 \mathrm{mg} / \mathrm{kg})$ disrupted place preference to $5 \mathrm{mg} / \mathrm{kg}$ cocaine. In addition, mice lacking the high affinity $n A C h R$ containing the $\beta 2$ subunit showed decreased place preference to $5 \mathrm{mg} / \mathrm{kg}$ cocaine, although higher doses of cocaine could condition a place preference in these knock out animals. In contrast, co-administration of a low dose of nicotine $(0.2 \mathrm{mg} / \mathrm{kg})$ potentiated place preference to a subthreshold dose of cocaine (3 $\mathrm{mg} / \mathrm{kg})$. DA turnover was monitored in several brain regions using tissue levels of $D A$ and its primary metabolite DOPAC as an indication of DA release. Wild type mice showed decreased DA turnover following treatment with $5 \mathrm{mg} / \mathrm{kg}$ cocaine; whereas, this response was not seen in mice lacking the $\beta 2$ subunit of the $n A C h R$. Induction of chronic fos-related antigens by cocaine was also reduced in mutant mice as compared to their wild type siblings, implying that downstream actions of cocaine were also affected by inactivation of the high affinity $n A C h R$. These data indicate that activation of the high affinity $n A C h R$ may contribute to cocaine reinforcement. Neuropsychopharmacology 24:576-589, 2001] (C) 2001 American College of Neuropsychopharmacology. Published by Elseiver Science Inc.
KEY WORDS: Place preference; Cocaine; Nicotine; Knock out mice; Morphine; Nucleus accumbens

Nicotine, the primary addictive substance in tobacco (Stolerman and Jarvis 1995), exerts its psychoactive effects through stimulation of a number of neurotransmitter pathways (Picciotto 1998). In particular, the reinforcing effects of nicotine are thought to be mediated through activation of the mesolimbic dopamine (DA) system (Corri-

From the Department of Psychiatry (VZ, BJC, A W-L, TPG, JDE, RHR, MRP), Yale University School of Medicine, Yale University, New Haven, Connecticut, USA; and CNRS UA D1284-Neurobiologie Moléculaire (J-PC), Institut Pasteur, Paris, France.

Address correspondence to: Marina R. Picciotto, Department of Psychiatry, Yale University School of Medicine, 34 Park Street-3rd floor research, New Haven, CT 06508, USA. 2000.

Received May 17, 2000; revised August 14, 2000; September 27, gall et al. 1994, 1992; Pontieri et al. 1996). Mice lacking the $\beta 2$ subunit of the nicotinic acetylcholine receptor (nAChR) have been used to help elucidate the mechanisms underlying the actions of nicotine on the dopaminergic system. These animals are healthy, reproduce, appear normal in many behaviors, but lack high affinity binding sites for nicotine in the brain (Picciotto et al. 1995, 1997). In contrast to wild type mice, knock out mice lacking the $\beta 2$ subunit of the nAChR show no increase in the firing rate of dopaminergic neurons upon stimulation with nicotine (Picciotto et al. 1998). Furthermore, unlike what is seen in wild type animals, no increase in extracellular DA levels is seen following systemic treatment with nicotine in these knock out mice, and nicotine self-administration is disrupted (Picciotto et al. 1998). Although these experiments demonstrate a role for the $\beta 2 \mathrm{nAChR}$ subunit in neurochemical and behavioral processes associated with nico- 
tine reinforcement, it is not clear whether nAChRs containing the $\beta 2$ subunit contribute to control of the dopamine system under physiological conditions in the absence of nicotine. We hypothesize that tonic stimulation of the high affinity subclass of $\mathrm{nAChRs}$ by acetylcholine physiologically regulates dopaminergic neurotransmission. Indeed, the source of acetylcholine impinging on the terminals of these neurons are the large, striatal interneurons; whereas, the peduncuplopontine tegmental nucleus innervates the cell bodies in the ventral tegmental area (VTA). Both these populations of cholinergic neurons have been shown to be tonically active (Di Chiara et al. 1994). Thus, removing the regulation of dopamine neurons through high affinity nicotine receptors should result in decreased basal activity of the DA system that can be revealed by pharmacological challenges that affect this system.

Like nicotine, cocaine and other drugs of abuse can increase levels of extracellular DA in the nucleus accumbens (NAc) through different molecular mechanisms (Dani and Heinemann 1996; Koob 1992; Pontieri et al. 1996). Several studies support a link between nicotine treatment and cocaine reinforcement. For example, preexposure of rats to nicotine increased self-administration of cocaine (Horger et al. 1992) and nicotine has been shown to enhance (Reid et al. 1998), and mecamylamine can attenuate (Reid et al. 1999) cue-induced craving of cocaine in human subjects. It is, therefore, possible that interaction between these drugs may occur in the mesolimbic DA pathway. Because cocaine exerts its effects through inhibition of DA reuptake, its efficacy is limited by the amount of DA released and available in the extracellular space. Thus, inactivation of nAChRs should result in less DA in the extracellular space for cocaine to act upon. Cocaine reinforcement could, thus, be used as a marker of DA regulation by activation of $n A C h R s$.

In this study, we investigate the effects of nAChRs on cocaine reinforcement. We have also investigated the molecular mechanism underlying this interaction using knock out mice lacking the high affinity receptor for nicotine. The data presented here indicate that activity of the endogenous nicotinic acetylcholine system may contribute to the reinforcing effects of cocaine, even in the absence of exogenous nicotine. In these studies, cocaine place preference was significantly attenuated by inactivation of $\mathrm{nAChRs}$. In contrast, morphine place preference was not altered in mice lacking the high affinity receptor for nicotine. These experiments support the hypothesis that the endogenous cholinergic system might contribute to tonic regulation of the DA system.

\section{MATERIALS AND METHODS}

\section{Animals}

Male and female C57Bl/6J mice (24-28g), obtained from Jackson Laboratories, Bar Harbor, ME, were used in the present study. $\beta 2$ subunit knock out mice were bred in the laboratory from animals back-crossed for more than 10 generations to $\mathrm{C} 57 \mathrm{Bl} / 6 \mathrm{~J}$ mice, and wild type siblings were used as controls. Mice were $3-5$ months old at the time of testing. Both male and female $\beta 2-/-$ and $\beta 2+/+$ knock out mice were used for place preference testing. No differences in cocaine or morphine place preference were observed between genders (cocaine 5 $\mathrm{mg} / \mathrm{kg}$ : males $=227 \pm 76$, females $=224 \pm 53$; cocaine $20 \mathrm{mg} / \mathrm{kg}$ : males $=244 \pm 64$, females $=243 \pm 64$ ), thus behavioral data from male and female animals were pooled. Mice were housed in a temperature and humidity controlled vivarium, provided food and water ad libitum and were maintained on a 12-hour dark/light cycle, and behavioral experiments were performed during the light cycle. All experiments were conducted in accordance with the NIH Guide for the Care and Use of Laboratory Animals.

\section{Place Preference}

A clear plastic cage $25.4 \mathrm{~cm}$ high $\times 50 \mathrm{~cm}$ long $\times 25.4$ $\mathrm{cm}$ wide was used to construct the place preference apparatus, which consisted of a $25-\mathrm{cm}$ square compartment with white smooth plastic flooring and white walls and a second $25-\mathrm{cm}$ square compartment with black-mesh flooring and black and white striped (3-cm wide) walls (Zachariou et al. 1999). The two compartments were separated by a $10-\mathrm{cm}$ wide aluminum platform and a divider separated the two compartments during training sessions. On test days, a door in the divider was raised to allow access to both compartments. To provide dim illumination and prevent interference from other environmental cues in the room, the Lucite cover of each cage was wrapped in waxed paper. Movement between compartments was detected by infrared photobeam detectors and transducers set $1.5 \mathrm{~cm}$ above the floor of the apparatus, and activity was monitored using an IBM computer and custom software designed for measuring place preference. Animals were considered to be on one side once no beams were blocked in either the opposite compartment or the aluminum platform in the center of the apparatus.

Animals were moved into the testing room immediately before the beginning of a conditioning or testing session. On day 1, animals were weighed and placed in cages without floors for $5 \mathrm{~min}$ for habituation to handling and the test environment. On day 2, animals were placed on the central aluminum platform and allowed to explore both compartments for $30 \mathrm{~min}$ to determine their initial preference between the two compartments. The same test was repeated on day 3 , and the initial preference was calculated as the average time spent in each compartment on day 2 and day 3. Animals that spent more than 10 minutes on the central aluminum platform or more than $75 \%$ of the time in the preferred compart- 
ment during initial preference determination were excluded from the study. The remaining animals were randomly assigned to two groups. On days 4-9, animals received drug injections and were immediately confined to the less preferred compartment (group 1: days 4, 6, 8; group 2: days $5,7,9)$ or received vehicle injections and were immediately placed in the preferred compartment (group 1: days 5, 7, 9; group 2 days 4, 6, 8). Conditioning sessions lasted 15 minutes. On day 10, the animals were placed on the central platform and were allowed to explore both compartments again for $30 \mathrm{~min}$. The time spent in the drug-paired compartment on the final test day was then compared to the time spent in that compartment before conditioning. Each animal received only one drug treatment. Cages were washed thoroughly with water and $70 \%$ ethanol between each session.
All drugs were administered IP except morphine, which was administered SC. For chronic-intermittent nicotine administration, animals were injected once per day for 10 days in the home cage with either nicotine $(0.7 \mathrm{mg} / \mathrm{kg}$, Sigma, St. Louis, MO) or saline in a volume of $100 \mu \mathrm{l}$. After 10 days, place preference testing was initiated, and nicotine was injected at least $6 \mathrm{~h}$ following training throughout the remaining days of the experiment. No change in baseline preference was seen in mice that received chronic nicotine treatment as compared to other groups of mice.

Groups were as follows:

A) Cocaine and morphine dose response study: (1) saline (cocaine group: $n=10$, morphine group: $n=13)$; (2) 3 $\mathrm{mg} / \mathrm{kg}$ (cocaine: $n=12$, morphine: $n=14$ ); (3) $5 \mathrm{mg} /$

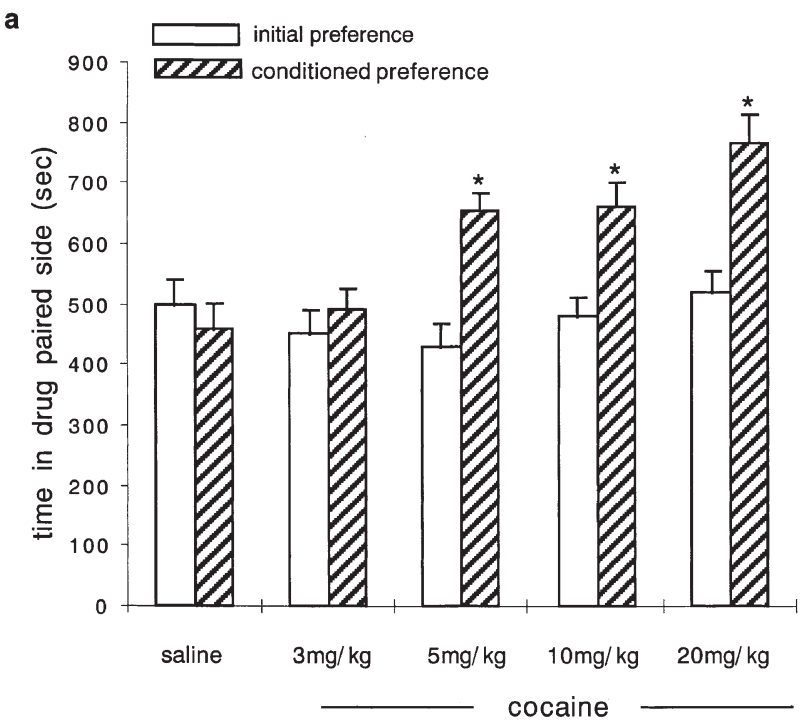

b

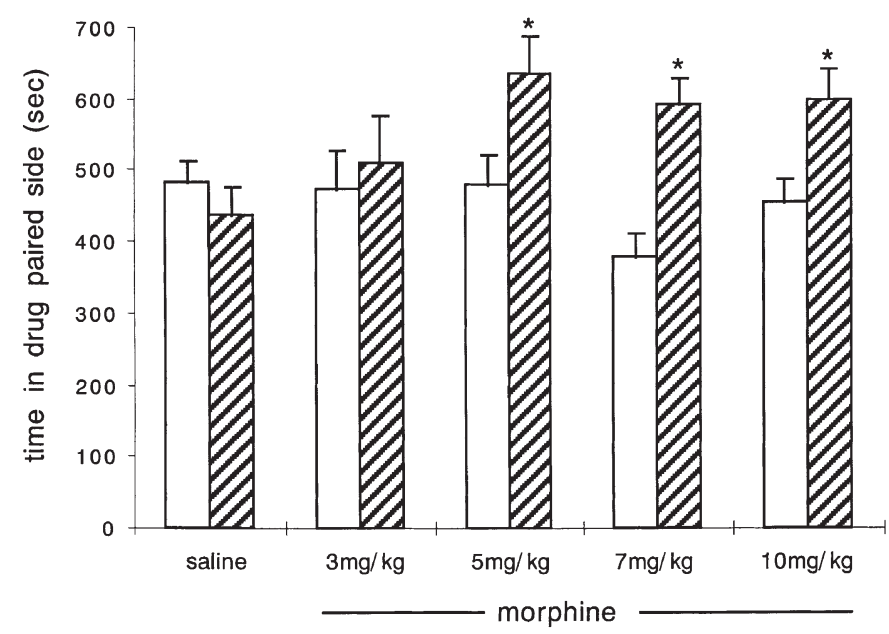

Figure 1. Determination of the lowest doses of cocaine and morphine that can condition a place preference in $\mathrm{C} 57 \mathrm{Bl} / 6$ mice. Data are represented as total time (s) spent in the drug-paired compartment pre- and postconditioning \pm S.E.M. Cocaine dose-response: saline, 3, 5, 10, and $20 \mathrm{mg} / \mathrm{kg}$ of cocaine. Morphine dose-response: saline, 3, 5, 7, and 10 mg/kg of morphine ANOVA: $p<.005 ;{ }^{*}$ : significant difference for drug treatment vs. preconditioning. 
$\mathrm{kg}$ (cocaine: $n=12$, morphine: $n=12) ;(4) 7 \mathrm{mg} / \mathrm{kg}$ (morphine: $n=10$ ); (5) $10 \mathrm{mg} / \mathrm{kg}$ (cocaine: $n=7$, morphine: $n=9$ ); (6) $20 \mathrm{mg} / \mathrm{kg}$ (cocaine: $n=15$ ).

B) Cocaine-mecamylamine studies: (1) $1 \mathrm{mg} / \mathrm{kg}$ mecamylamine $(n=12) ;(2) 5 \mathrm{mg} / \mathrm{kg}$ cocaine $(n=13)$ (3) 5 $\mathrm{mg} / \mathrm{kg}$ cocaine $+1 \mathrm{mg} / \mathrm{kg}$ mecamylamine $(n=12) ;$ (4) $10 \mathrm{mg} / \mathrm{kg}$ cocaine $(n=8) ;(5) 10 \mathrm{mg} / \mathrm{kg}$ cocaine + $1 \mathrm{mg} / \mathrm{kg}$ mecamylamine $(n=11)$.

C) Cocaine place preference study in $\beta 2$ subunit knock out mice: (1) saline $\left(\beta_{2}+/+, n=12 ; \beta_{2}-/-, n=11\right)$; (2) 5 $\mathrm{mg} / \mathrm{kg}$ cocaine $\left(\beta_{2}+/+, n=13 ; \beta_{2}-/-, n=12\right) ;(3)$; $10 \mathrm{mg} / \mathrm{kg}$ cocaine $\left(\beta_{2}+/+, n=16 ; \beta_{2}-/-, n=14\right)$.

D) Morphine place preference study in $\beta 2$ subunit knock out mice: saline $\left(n=6 \beta_{2}+/+\right.$ and $\left.6 \beta_{2}-/-\right)$ and $5 \mathrm{mg} / \mathrm{kg}$ morphine, SC. $\left(\beta_{2}+/+, n=12 ; \beta_{2}-/-, n=11\right)$.

E) Cocaine-chronic-intermittent nicotine studies: (1) chronic saline $/ 5 \mathrm{mg} / \mathrm{kg}$ cocaine acutely $(n=10) ;(2)$ chronic nicotine $(0.7 \mathrm{mg} / \mathrm{kg}) / 5 \mathrm{mg} / \mathrm{kg}$ cocaine acutely $(n=8)$;

F) Cocaine + nicotine place preference studies: (1) nicotine $0.2 \mathrm{mg} / \mathrm{kg}+$ saline $(n=8) ;(2)$ cocaine $3 \mathrm{mg} /$ $\mathrm{kg}+$ saline $(n=8)$; (3) cocaine $3 \mathrm{mg} / \mathrm{kg}+$ nicotine 0.2 $\mathrm{mg} / \mathrm{kg}(n=8)$.

\section{DA Turnover}

$\beta 2+/+$ and $\beta 2-/-$ mice ( $n=10$ per group) were injected with either saline or $5 \mathrm{mg} / \mathrm{kg}$ cocaine. Thirty $\mathrm{min}$ after injection, mice were sacrificed by rapid decapitation, and brains were dissected into cortex, striatum/telencephalon, and brainstem, frozen on dry ice, and stored at $-70^{\circ} \mathrm{C}$ for later high-performance liquid chromatography (HPLC) analysis of monoamine concentrations. DA and its major metabolite, dihydroxyphenylacetic acid (DOPAC), were quantitated using HPLC with electrochemical detection (HPLC-ED) with a glassy carbon electrode set at $+0.7 \mathrm{~V}$ and an $\mathrm{Ag} / \mathrm{AgCl}$ reference electrode. The procedure involved homogenization of frozen tissue by sonication in $0.3 \mathrm{ml}$ of $0.1 \mathrm{M}$ perchloric acid containing $8 \mathrm{ng}$ of 3,4-dihydroxybenylzamine (DHBA), followed by alumina extraction on microcolumns. Catecholamines are retained on the alumina microcolumns and then eluted with $0.1 \mathrm{M}$ oxalic acid. The oxalic acid eluates were then injected onto a reverse phase 3-micron C18 HPLC column (Rainin Instruments, Woburn, MA). The mobile phase, delivered at $0.65 \mathrm{ml} / \mathrm{min}$, was composed of sodium citrate $(30$ $\mathrm{mM})$, sodium dihydrogen phosphate $(14 \mathrm{mM})$, sodium octanesulphonate $(2.3 \mathrm{mM})$, EDTA $(0.025 \mathrm{mM})$, acetonitrile $(6.5 \%)$, tetrahydrofuran $(0.6 \%)$, and diethylamine $(0.1 \%)$, adjusted to $\mathrm{pH} 3.10$ with concentrated phosphoric acid. Dihydroxybenzamine was used as an internal standard and used to calculate percentage recovery of DOPAC and DA. Results are expressed as the ratio of DOPAC to DA, with tissue levels calculated in $\mathrm{ng} / \mathrm{mg}$ protein. Protein concentrations were determined by the

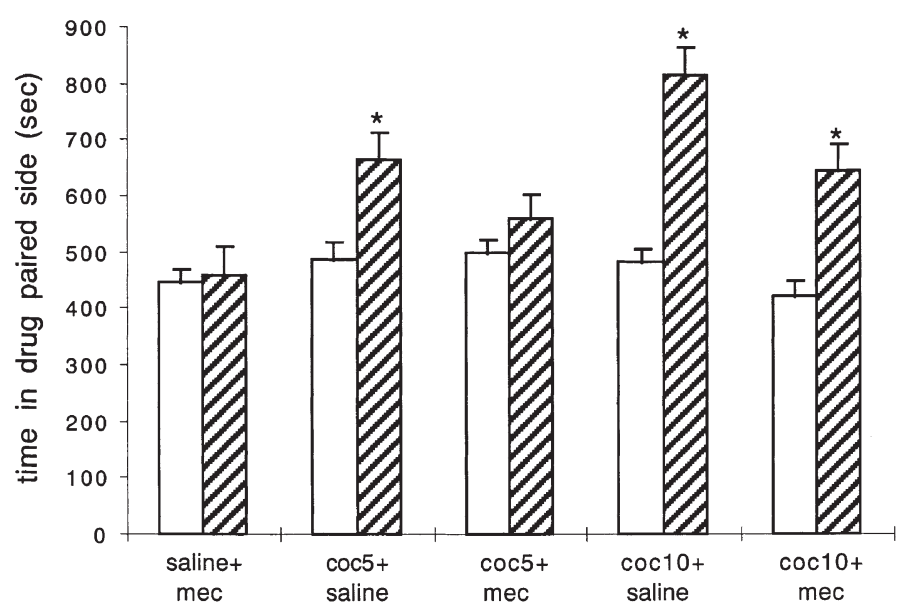

Figure 2. Mecamylamine blocks cocaine place preference in $\mathrm{C} 57 \mathrm{Bl} / 6$ mice. saline + mec: co-treatment with saline and mecamylamine $(1 \mathrm{mg} / \mathrm{kg})$; coc5+saline: co-treatment with cocaine $(5 \mathrm{mg} / \mathrm{kg})$ and saline; coc5+mec: co-treatment with cocaine $(5 \mathrm{mg} / \mathrm{kg})$ and mecamylamine $(1 \mathrm{mg} / \mathrm{kg})$; coc10+saline: co-treatment with cocaine $(10 \mathrm{mg} / \mathrm{kg})$ and saline; coc $10+$ mec: co-treatment with cocaine $(10 \mathrm{mg} / \mathrm{kg})$ and mecamylamine $(1 \mathrm{mg} / \mathrm{kg})$, ANOVA: $p<.005$; *: significant difference for post- vs. preconditioning. 
method of Lowry (Lowry et al. 1957). Three independent experiments were performed with very similar results, and data were pooled for statistical analysis.

\section{Western Blotting}

$\beta 2+/+$ and $\beta 2-/-$ mice ( $n=9$ per group) were treated with cocaine $(20 \mathrm{mg} / \mathrm{kg})$ or saline once a day for 6 days and were sacrificed 20-24 hours after the last injection. Brains were dissected and nucleus accumbens was isolated from a 1-mm slice using a 14-gauge needle. Tissue was homogenized in $1 \%$ sodium dodecyl sulfate (SDS), and protein concentration was measured using the Lowry method. One hundred $\mu \mathrm{g}$ protein per lane was separated on a $10 \%$ acrylamide gel by sodium dodecyl sulfate-poly-acrylamide gel electrophoresis (SDS-PAGE) and transferred to nitrocellulose for western blotting. The nitrocellulose membrane was blocked with $2 \%$ nonfat dry milk and incubated with primary antiserum at the appropriate concentration (1:1000 for fosB antiserum (Santa Cruz sc048, Santa Cruz, CA) and 1:5000 for GluR1 antiserum (Chemicon AB1504, Temecula, CA) at $4^{\circ} \mathrm{C}$ overnight. Each membrane was divided in two parts, one part (below $56 \mathrm{kDa}$ ) was incubated using the fosB antiserum, and the other part was incubated using the GluR1 antiserum. Following overnight incubation, membranes were washed $3 \times 20 \mathrm{~min}$ in TBS-Tween buffer and then incubated for 2 hours with

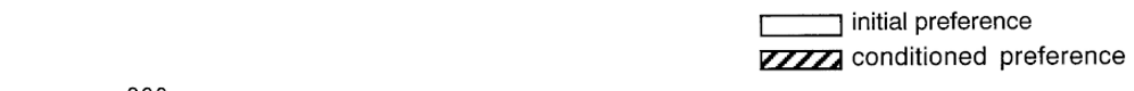

a

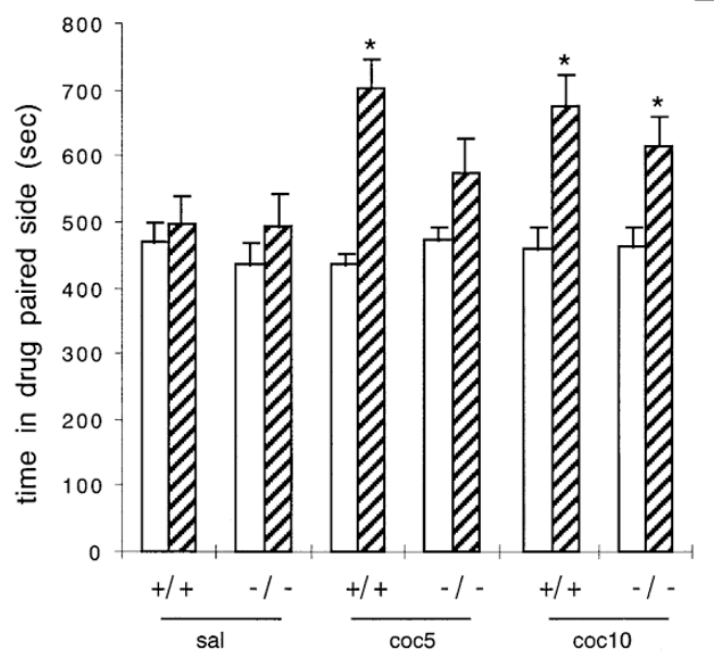

b

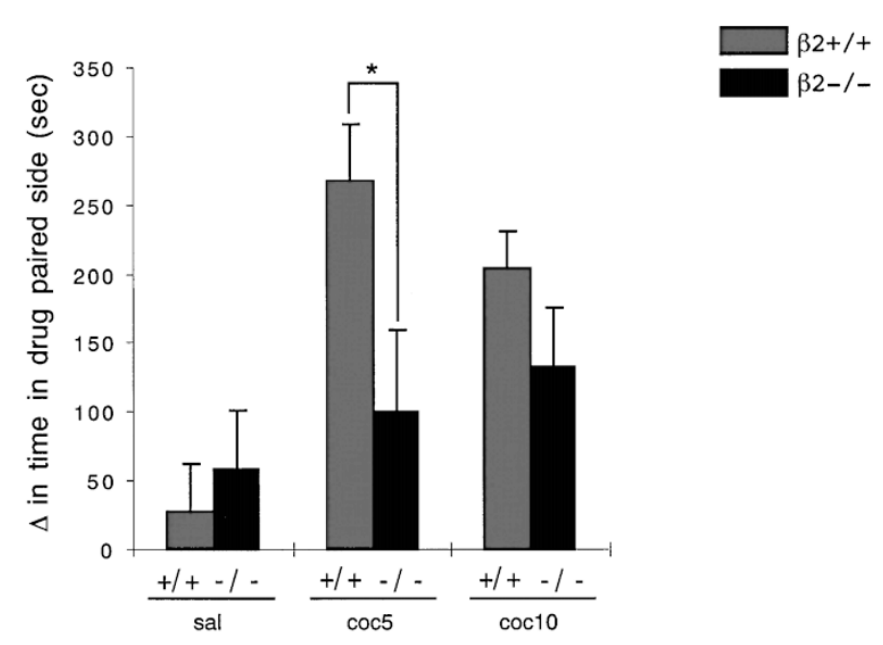

Figure 3. Cocaine place preference in mice lacking the high affinity neuronal nicotinic receptor. a) Comparison of total time (s) spent in the drug paired compartment pre- and postconditioning \pm S.E.M.; b) Comparison of difference in time (s) spent in the drug-paired compartment in wild type and $\beta 2$ subunit knock out mice. $+/+$ : wild type animals; $-/-: \beta_{2}$ subunit knock out mice; sal: saline; coc5: cocaine $(5 \mathrm{mg} / \mathrm{kg})$; coc10: cocaine $(10 \mathrm{mg} / \mathrm{kg})$. a) ANOVA: $p<.005$; ${ }^{*}$ : significant difference for post- vs. preconditioning. b) ANOVA: $p>.005$; * significant difference for cocaine treatment in $\beta 2-/-$ vs. $\beta 2+/+$ mice. 
horseradish peroxidase conjugated goat antirabbit IgG (1:3000, Vector, Burlingame, CA). Immunoreactivity was detected using chemiluminescence (Amersham, Piscataway, NJ). Levels were quantified by measuring the optical density of specific bands ( $35 \mathrm{kDa}$ for fosB and $108 \mathrm{kDa}$ for GluR1) using NIH image.

\section{Statistical Analysis}

Data for place preference and biochemical experiments are presented as average \pm SEM. For the biochemical studies, statistical analysis was performed using Student's $t$-test or analysis of variance (ANOVA) for repeated measures followed by the least-significant difference multiple range post-hoc test. For place preference studies, statistical analysis was performed using ANOVA for repeated measures followed by the least-significant difference multiple range post-hoc test. The level of significance was set at $p<.05$.

\section{RESULTS}

The ability of $3,5,10$, and $20 \mathrm{mg} / \mathrm{kg}$ of cocaine to condition a place preference in C57Bl/ 6 mice is shown in Figure 1A. The lowest dose of cocaine that could condition a place preference in these animals was $5 \mathrm{mg} / \mathrm{kg}$. Data are expressed as time spent in the drug-paired side be- fore and after conditioning. The lowest morphine dose that was able to condition a place preference in $\mathrm{C} 57 \mathrm{Bl} / 6$ mice was $5 \mathrm{mg} / \mathrm{kg}$ SC (Figure 1B).

To investigate whether inactivation of $\mathrm{nAChRs}$ affects cocaine reinforcement, an acute dose $(1 \mathrm{mg} / \mathrm{kg})$ of the nicotinic antagonist mecamylamine was co-administered with each injection of 5 or $10 \mathrm{mg} / \mathrm{kg}$ cocaine (Figure 2). Mecamylamine alone did not condition a place preference or a place aversion, but when co-administered with $5 \mathrm{mg} / \mathrm{kg}$ cocaine, $1 \mathrm{mg} / \mathrm{kg}$ mecamylamine decreased cocaine place preference. A higher cocaine dose $(10 \mathrm{mg} / \mathrm{kg})$ overcame the effect of mecamylamine and conditioned a place preference when co-administered with the nicotinic antagonist.

The nicotinic subtypes that might be involved in this interaction were determined using mice lacking the $\beta 2$ subunit of the nAChR. The responses of $\beta 2-/-$ mice and their $\beta 2+/+$ siblings to cocaine conditioning is shown in Figure 3. Cocaine at $5 \mathrm{mg} / \mathrm{kg}$ significantly increased the time spent in the drug-paired side by an average of $170 \mathrm{~s}$ in $\beta 2+/+$ mice but did not condition a significant place preference in $\beta 2-/-$ mice. At a higher dose of cocaine $(10 \mathrm{mg} / \mathrm{kg})$, no significant difference was seen between $\beta 2-/-$ and wild type mice, although there was a trend for the $\beta 2-/-$ mice to show decreased place preference at this dose as well. These data indicate that the dose-response curve for cocaine place preference is shifted to the right in mice lacking

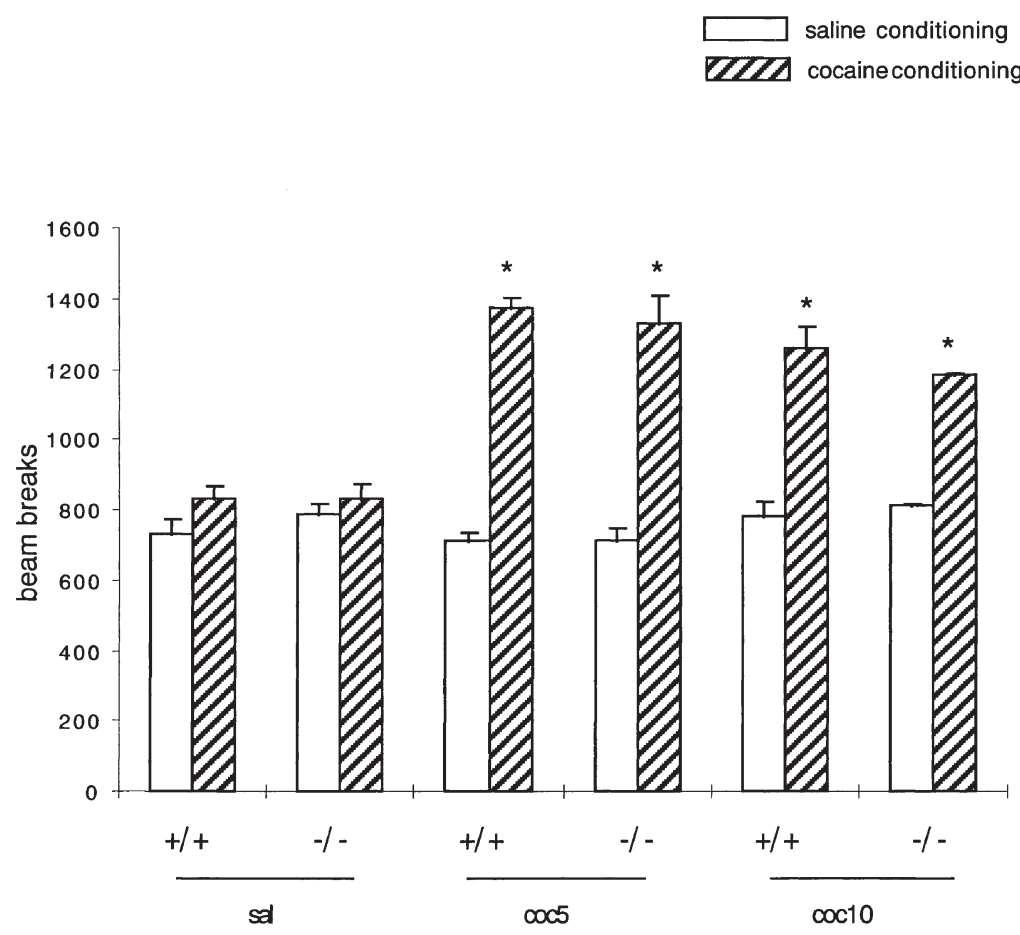

Figure 4. Locomotor activity during cocaine place conditioning. Data are represented as average number of beam breaks per 15 min over 3 saline-conditioning days (open bars) or 3 cocaine-conditioning days (striped bars). No sensitization was seen using this regimen. Groups were the same as those presented in Figure 3. ANOVA: $p<.005$ cocaine vs. saline. 
the high affinity receptor for nicotine. Locomotor activity was stimulated by 5 and $10 \mathrm{mg} / \mathrm{kg}$ cocaine, but no differences were seen between wild type and knock out animals (Figure 4 ). In contrast, $\beta 2-/-$ animals respond to a threshold dose of morphine similarly to $\beta 2+/+$ animals, indicating that this effect is unlikely to be attributable to inability to acquire a place preference or a generalized abnormality in the pathways underlying this behavior (Figure 5).

We then tested the effect of repeated nicotine treatment on cocaine-conditioned place preference. Chronicintermittent nicotine treatment was chosen, because it mimics some features of the pattern of nicotine exposure of cigarette smokers. When $\mathrm{C} 57 \mathrm{Bl} / 6$ mice were pretreated for 10 days with $0.7 \mathrm{mg} / \mathrm{kg}$ nicotine, $5 \mathrm{mg} / \mathrm{kg}$ of cocaine did not condition a significant place preference (Figure 6). Mice that received the 10-day nicotine pretreatment showed tolerance to the locomotor depressant effects of an acute injection of $1 \mathrm{mg} / \mathrm{kg}$ nicotine (not shown), possibly indicating that this treatment leads to progressive inactivation of nAChRs (Marks et al. 1991, 1993) resulting in perturbation of the mechanisms which mediate cocaine-conditioned place preference.

If inactivation of nAChRs can shift the cocaine dose response to the right, we hypothesized that activation of nAChRs should shift the cocaine dose response to the left in the place preference paradigm. Because $5 \mathrm{mg} / \mathrm{kg}$ of cocaine was the lowest dose that conditioned a place preference in our paradigm, we investigated whether place conditioning could be produced by $3 \mathrm{mg} / \mathrm{kg}$ cocaine co-administered with a low nicotine dose $(0.2$ $\mathrm{mg} / \mathrm{kg}$ ). These low doses of nicotine and cocaine do not condition a place preference on their own (Figure 7), but co-administration of $0.2 \mathrm{mg} / \mathrm{kg}$ nicotine with $3 \mathrm{mg} /$ $\mathrm{kg}$ cocaine resulted in a significant place preference. This finding further supports the hypothesis that the cholinergic system modulates cocaine reinforcement.

The interaction between nicotine and cocaine could take place at the level of the dopaminergic system. To investigate the mechanism underlying the cocainenicotine interaction, mice were sacrificed $30 \mathrm{~min}$ following an acute cocaine $(5 \mathrm{mg} / \mathrm{kg})$ or saline injection, and striatum/telencephalon, cortex, and brainstem extracts were assayed for DOPAC and DA levels using HPLC (Figure 8). Acute treatment with $5 \mathrm{mg} / \mathrm{kg}$ cocaine would be analogous to the dose used to condition a place preference to a threshold dose of cocaine in behavioral experiments. Striatal/telencephalic DOPAC/DA ratios were significantly reduced $(p=$ .01) following cocaine administration in $\beta_{2}+/+$ mice (saline: $0.070 \pm 0.001 ; 5 \mathrm{mg} / \mathrm{kg}$ cocaine: $0.060 \pm 0.001$ ), as has been seen in other mouse strains (Hadfield 1995; Hadfield and Milio 1992). In contrast, no significant difference was seen in the ratio of DOPAC/DA following cocaine treatment in $\beta_{2}-/-$ mice (saline: $0.062 \pm 0.001 ; 5 \mathrm{mg} / \mathrm{kg}$ cocaine: $0.060 \pm 0.001$ ). The base- line ratio of DOPAC/DA in striatum/telencephalon and cortex showed a nonsignificant trend to being higher in $\beta_{2}+/+$ mice than in $\beta_{2}-/-$ mice, suggesting that baseline DA utilization may be decreased in knock out mice. No significant differences were seen in DOPAC/DA ratios in brainstem, or in DA levels across genotypes and treatments in each brain area (Table 1).

One of the downstream effects of chronic cocaine administration is the induction of a long-lasting activation protein 1 (AP-1) DNA-binding complex in the NAc and dorsal striatum, which is manifested by the
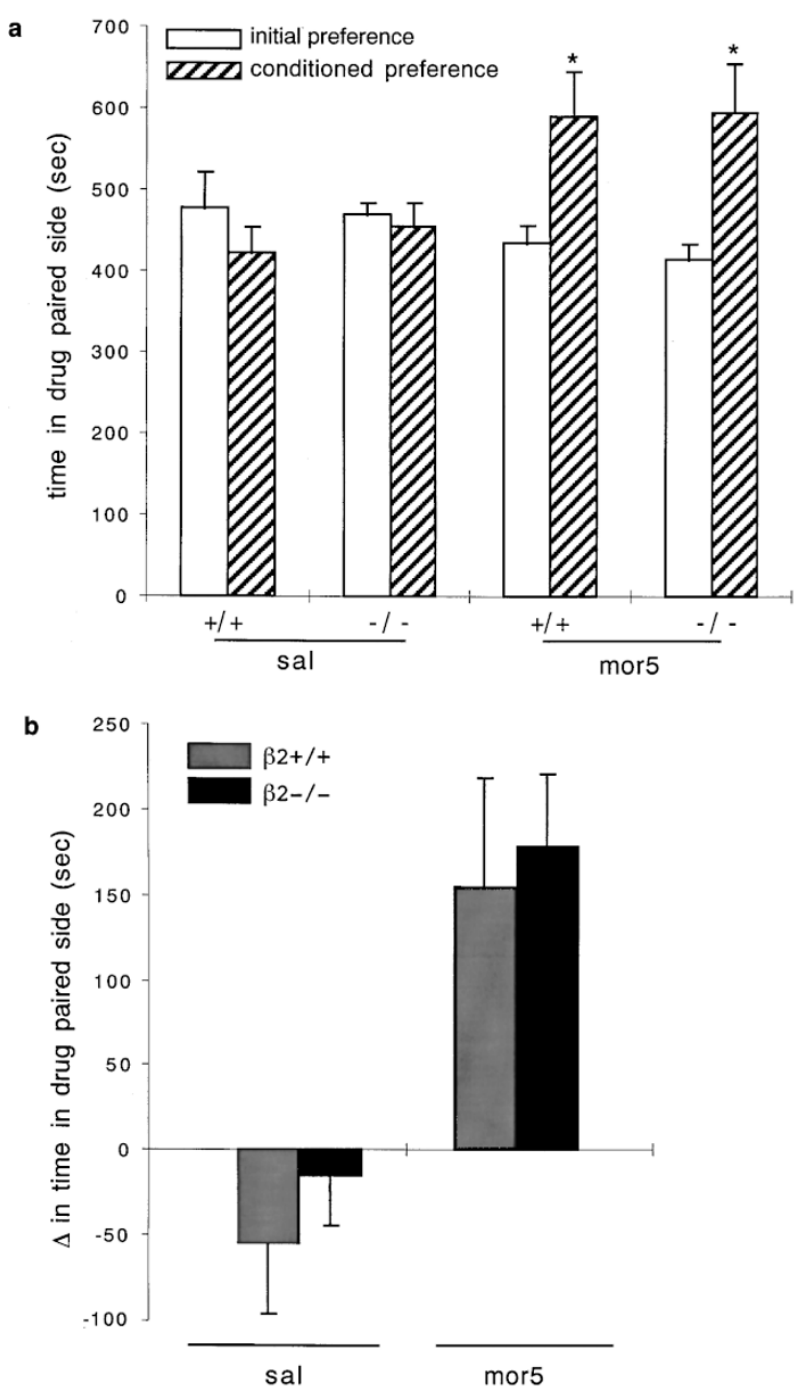

Figure 5. Morphine place preference in mice lacking the high affinity neuronal nicotinic receptor. a) Comparison of total time(s) spent in the drug-paired compartment pre- and postconditioning \pm S.E.M. b) Comparison of difference in time(s) spent in the drug paired compartment in wild type and $\beta 2$ subunit knock out mice. $+/+$ : wild type animals; $-/-$ : $\beta_{2}$ subunit knock out mice; sal: saline; mor5: morphine (5 mg/kg). A) ANOVA: $p<.005$; *: significant difference for post- vs. preconditioning. 


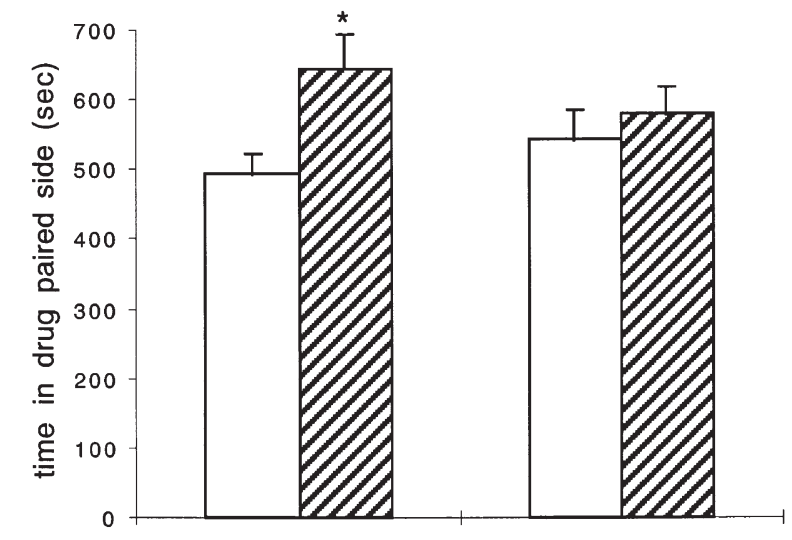

$\begin{array}{rcc}\text { pretreatment } & \text { saline } & \text { nicotine } \\ \text { acute } & \text { coc5 } & \operatorname{coc} 5\end{array}$

Figure 6. Effect of chronic-intermittent nicotine treatment on cocaine place preference. Nicotine was injected once a day for 10 days before cocaine conditioning started, and injections continued during the conditioning period at least 6 hours following the session. Data are expressed as total time (s) spent in the drug-paired compartment pre- and postconditioning. Groups are: Saline pretreatment/acute cocaine ( $5 \mathrm{mg} / \mathrm{kg})$; nicotine pretreatment $(0.7 \mathrm{mg} / \mathrm{kg}, 10$ days $) /$ acute cocaine (5 mg/ $\mathrm{kg}$ ). ANOVA: $p<.005$; * significant difference for postconditioning vs. preconditioning.

expression of the 35- and 37-kDa Fos-related proteins (chronic fras) derived from a splice variant of the Fos-B gene (Hiroi et al. 1997). Although induction of chronic fras by chronic injections of cocaine was significantly increased in wild type mice, no change in chronic fras induction was seen following cocaine treatment in $\beta_{2}-/-$ mice, implying that some downstream neurochemical effects of cocaine, perhaps mediated through activation of the DA system, are decreased as a result of $\mathrm{nAChR}$ inactivation (Figure 9A). Basal levels of chronic fras were not different between wild type and knock out animals. Levels of the GluR1 subunit of the AMPA receptor, which do not change in the NAc following cocaine administration (Fitzgerald et al. 1996; Ghasemzadeh et al. 1999), were used as an internal control on the same blots and did not change across any of the treatments or genotypes of mice in this study (Figure 9B).

\section{DISCUSSION}

Cocaine can condition a place preference, and this is hypothesized to be a measure of the rewarding effects of the drug (Calcagnetti and Schechter 1993). We have shown that treatments that can inactivate nAChRs, including knock out of the high affinity subclass of the $\mathrm{nAChR}$ containing the $\beta 2$ subunit, or acute co-treatment with $1 \mathrm{mg} / \mathrm{kg}$ mecamylamine, can inhibit place preference to a threshold dose of cocaine, and that higher doses of cocaine overcome this inhibition. Although many mice with constitutive knock outs show adaptation to the genetic lesion, the similarity of the effect of the $\beta 2$ subunit knock out and acute mecamylamine treatment suggest that the effect on cocaine place preference is not simply the result of such an adaptation. In addition, acute administration of $0.2 \mathrm{mg} /$ $\mathrm{kg}$ nicotine can cause a subthreshold dose of cocaine to condition a place preference. These findings demonstrate that activation of $\mathrm{nAChRs}$ potentiates cocaine reinforcement. Furthermore, these receptors contain the $\beta 2$ subunit, similar to the nAChRs, which also mediate nicotine reinforcement (Picciotto et al. 1998). There may also be a contribution of homomeric nAChRs containing the $\alpha 7$ subunit to cocaine reinforcement, because direct infusion into the VTA of the $\mathrm{NAChR}$ antagonist methylycaconitine (which shows specificity for $\alpha 7$ subunitcontaining $\mathrm{nAChRs}$ at low concentrations) can decrease the effects of cocaine on brain-stimulation reward thresholds (Panagis et al. 2000). These findings are in 


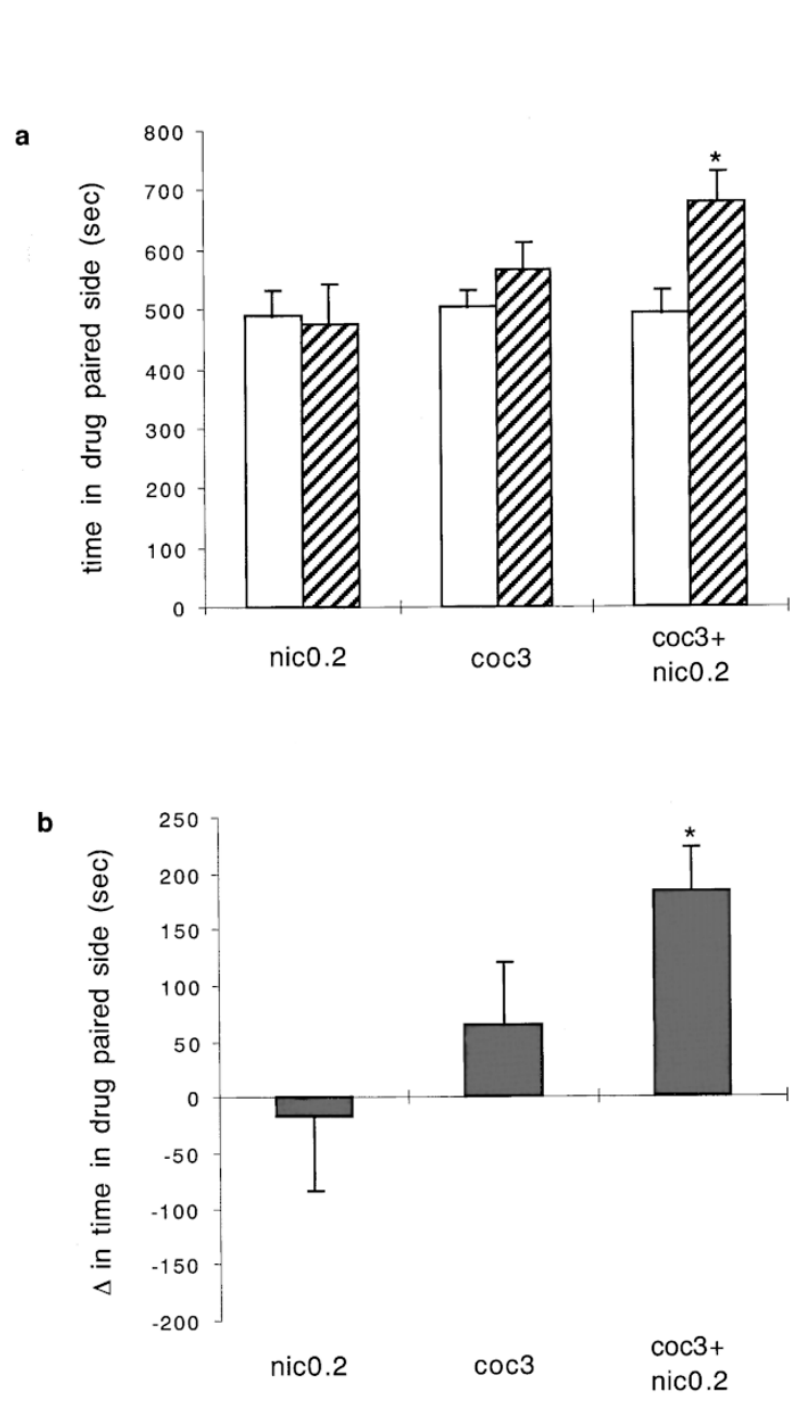

Figure 7. Effect of acute low-dose nicotine on cocaine place preference. a) total time (s) spent in the drug-paired compartment pre- and postconditioning. b) Difference in time(s) spent in the drug paired compartment after conditioning \pm S.E.M. nic 0.2 : nicotine $(0.2 \mathrm{mg} / \mathrm{kg})+$ saline; coc 3 : cocaine $(3 \mathrm{mg} / \mathrm{kg})+$ saline; coc $3+$ nic 0.2 : cocaine $(3 \mathrm{mg} / \mathrm{kg})+$ nicotine $(0.2 \mathrm{mg} /$ $\mathrm{kg}$ ). a) ANOVA: $p<.005$; * significant difference for post- vs. preconditioning. b) ANOVA: $p<.005$; ${ }^{*}$ significant difference for cocaine + nicotine treatment vs. saline co-treatments.

excellent correspondence with data from human subjects showing that mecamylamine reduces, and nicotine increases, cue induced cocaine craving (Reid et al. 1999, 1998).

The data shown here demonstrate that manipulations of the nicotinic system shift the threshold of cocaine place preference. Several groups have shown that place preference exhibits a very steep dose-response function, such that graded preference responses are not seen and a step-like response is seen to a dose above the threshold (Schechter and Calcagnetti 1993, 1998). Thus, a shift in the threshold dose of cocaine required to see the behavior is a sensitive measure of the efficacy of the drug.

In a previous study, $\beta 2$-subunit mutant mice on the C57Bl/ 6 background were first trained to self-adminis- ter cocaine stably and were subsequently switched to self-administer nicotine (Epping-Jordan et al. 1999; Picciotto et al. 1998). The study was designed so that differences in learning the self-administration task would not confound the finding that $\beta 2$ subunit knock out mice will not self-administer nicotine. Mice received IV injections of $0.8 \mathrm{mg} / \mathrm{kg}$ cocaine under a fixed ratio 1/ timeout $20 \mathrm{~s}$ schedule for two to four sessions until stable responding was observed. The results of the selfadministration study are consistent with the current study, because the cumulative dose of cocaine used in the training for IV self-administration is higher than the doses at which a significant attenuation of cocaine place preference was observed (three IP injections of $5 \mathrm{mg} / \mathrm{kg}$ cocaine over 6 days, which was overcome when higher 


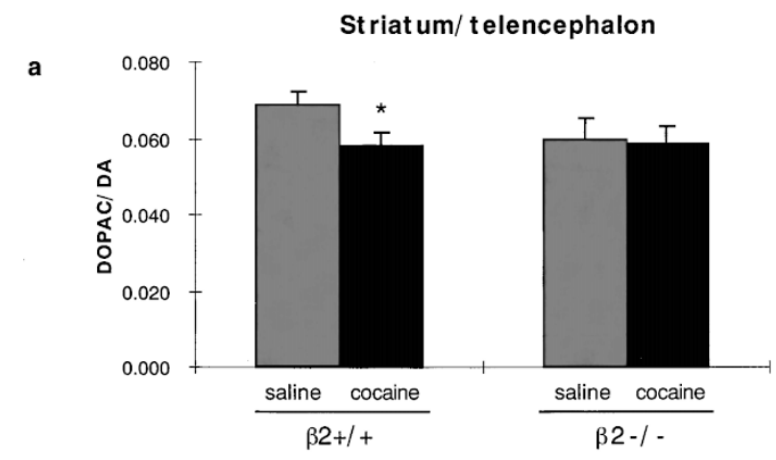

b
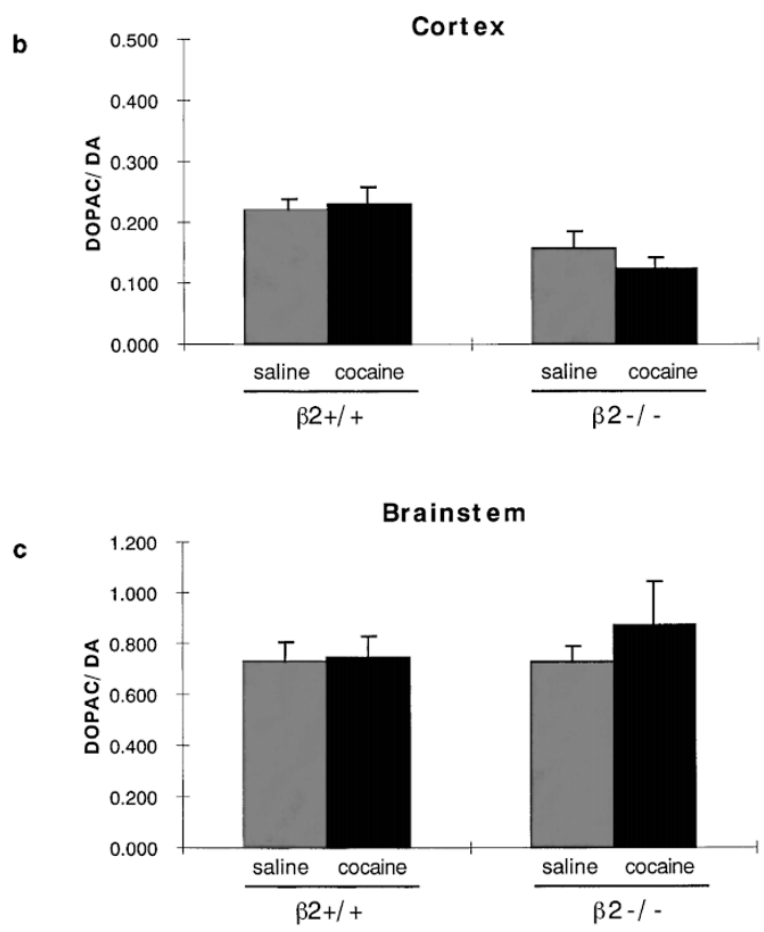

Figure 8. DOPAC/DA ratios in brain tissue from animals treated with saline or $5 \mathrm{mg} / \mathrm{kg}$ cocaine. Brains were dissected into cortex, striatum/telencephalon, and brainstem and homogenized for HPLC detection of DA and DOPAC. Tissue levels are calculated as $\mathrm{ng} / \mathrm{mg}$ protein. a) Striatum/ telencephalon. b) Cortex. c) Brainstem. $\beta 2+/+$ : wild type mice; $\beta 2-/-$ : knock out mice; saline: acute saline treatment; cocaine: acute treatment with cocaine $(5 \mathrm{mg} / \mathrm{kg}) .{ }^{*}, p=.01$, Student's $t$-test: cocaine vs. saline in wild type mice.

cocaine doses were used). Thus, it is not surprising that the animals were able to acquire stable responding for cocaine. We might expect that differences in acquisition of cocaine self-administration could be observed between $\beta 2$ knock out mice and their wild type littermates when lower doses of cocaine are used.

Current hypotheses of the mechanisms underlying the reinforcing effects of nicotine and cocaine implicate the mesolimbic dopaminergic pathway as the best candidate site for nicotine-cocaine interaction (Koob and Nestler 1997). Other candidate systems include the lim- bic serotonin system, which contributes to the reinforcing action of cocaine (Rocha et al. 1998) and which is modulated by nicotine ( $\mathrm{Li}$ et al. 1998; Mihailescu et al. 1998). Nicotine activates nAChRs located on dopaminergic neurons (Clarke and Pert 1985), increasing the firing rate of dopaminergic neurons through actions on the cell bodies (Grenhoff et al. 1986; Lichtensteiger et al. 1982; Mereu et al. 1987), and the release of DA from terminals in a synaptosome preparation (Grady et al. 1992). There is evidence for a consistent effect of nicotine on DA release through activation of nAChRs in the ventral tegmental area (Nisell et al. 1994). In contrast, mecamylamine can decrease the firing rate of mesolimbic DA neurons (Grenhoff et al. 1986) and can decrease the levels of extracellular DOPA as well as DA metabolites (Haikala and Ahtee 1988; Nakamura et al. 1992), implying that acetylcholine acting through nAChRs may contribute to the tonic activity of dopaminergic neurons. The effects of nicotine on the mesolimbic DA system are thought to mediate nicotine reinforcement, because a lesion of this brain area attenuates nicotine self-administration (Corrigall et al. 1992). Knock out mice lacking a single subunit of the neuronal $\mathrm{nAChR}$ (the $\beta 2$ subunit) lack high affinity nicotine binding throughout the brain (Picciotto et al. 1995; Zoli et al. 1998). These mice no longer show an increase in DA levels in response to nicotine treatment and will not self-administer nicotine (Picciotto et al. 1998), implying that the $\beta 2$ subunit is a necessary component of the $\mathrm{nAChR}$ mediating these effects. In contrast, cocaine acts in part by blocking the DA transporter, limiting reuptake of DA once it is released into the synapse upon firing of dopaminergic neurons (Koob 1992). Furthermore, D1 and D2 antagonists as well as lesions of the mesolimbic DA system are both able to disrupt cocaine place preference (Morency and Beninger 1986).

In this paper, we have examined the effects of nAChR inactivation on DA turnover and fos-related antigen expression in the basal ganglia, two parameters related to cocaine action on DA pathways. Low dose cocaine $(5 \mathrm{mg} / \mathrm{kg})$ is able to elicit a reduction in DOPAC/ DA ratio in $\beta 2+/+$ mice on the C57Bl/ 6 background, as has previously been shown in the ICR line of mice (Hadfield 1995; Hadfield and Milio 1992). In contrast, stimulation by $5 \mathrm{mg} / \mathrm{kg}$ cocaine is not sufficient to alter DA turnover in $\beta 2-/-$ mice. $\beta 2-/-$ mice also show a trend toward decreased basal DA turnover in the striatal/telencephalon regions of the brain, perhaps suggesting that DA utilization under basal conditions is altered in mice lacking the high affinity neuronal $\mathrm{nAChR}$. Although this is still a hypothesis, these data may imply that altered DA utilization in mice lacking high affinity nAChRs could be the primary mechanism involved in the decreased cocaine place preference seen in these animals. An alternate hypothesis is that phasic release of ACh results from the manipulation and han- 
Table 1. DOPAC/DA Ratios in Brain Stem. DA Levels Across Genotypes and Treatments in Each Brain Area

\begin{tabular}{|c|c|c|c|c|c|c|c|}
\hline \multirow[b]{2}{*}{ Genotype } & \multirow[b]{2}{*}{ Treatment } & \multicolumn{2}{|c|}{ Midbrain } & \multicolumn{2}{|c|}{ Cortex } & \multicolumn{2}{|c|}{ Brain stem } \\
\hline & & DA & DOPAC & DA & DOPAC & DA & DOPAC \\
\hline Wild type & Saline & $31.8 \pm 2.6$ & $2.16 \pm 0.14$ & $3.62 \pm 0.76$ & $0.57 \pm 0.10$ & $0.55 \pm 0.06$ & $0.38 \pm 0.03$ \\
\hline Wild type & Cocaine & $31.4 \pm 3.0$ & $1.81 \pm 0.14$ & $5.71 \pm 1.22$ & $0.68 \pm 0.12$ & $0.55 \pm 0.06$ & $0.36 \pm 0.04$ \\
\hline$\beta 2-/-$ & Saline & $30.2 \pm 3.4$ & $1.77 \pm 0.10$ & $3.24 \pm 0.82$ & $0.36 \pm 0.05$ & $0.49 \pm 0.06$ & $0.35 \pm 0.04$ \\
\hline$\beta 2-/-$ & Cocaine & $26.7 \pm 3.8$ & $1.61 \pm 0.27$ & $3.84 \pm 1.31$ & $0.35 \pm 0.09$ & $0.37 \pm 0.09$ & $0.27 \pm 0.03$ \\
\hline
\end{tabular}

Data are presented as means \pm SEM and are expressed as $\mathrm{ng} / \mathrm{mg}$ of protein. No significant differences in DA levels were seen within brain areas across genotype or treatment.

dling of the animals and that $\mathrm{nAChR}$ response to this phasic release is lost in knock out mice or wild type mice treated with mecamylamine.

Induction of fos-related antigens by chronic cocaine in the NAc and dorsal striatum has been demonstrated by several investigators (see e.g., Hiroi and Nestler 1998). Chronic fras induction has been shown to enhance sensitivity to cocaine, and thus when chronic fras are not induced normally, behavioral adaptations to chronic cocaine treatment may be attenuated (Kelz et al. 1999). This downstream response to cocaine is reduced in mice with a knock out of the $\beta 2$ subunit of the $\mathrm{nAChR}$, perhaps because of decreased activation of pathways downstream of the DA system following cocaine treatment in $\beta 2-/-$ animals. $20 \mathrm{mg} / \mathrm{kg}$ cocaine for 6 days seems to be the minimum dose that results in measurable induction of chronic fras (Hope et al. 1992), thus the loss of induction in the mutant animals is another indication that $\mathrm{nAChR}$ inactivation shifts the dose-response curve for cocaine to the right and results in decreased efficacy of threshold doses of cocaine.

Present and previous evidence on the actions of cocaine and nicotine suggest a hypothesis for the mechanism of how nAChRs might potentiate the effects of cocaine on the mesolimbic DA system. Activation of nAChRs in the mesolimbic DA system increases extracellular DA levels in the dorsal and ventral striatum. Acute nicotine administration can increase $\mathrm{nAChR}$ activation above that produced by endogenous ACh resulting in increased firing of mesolimbic DA neurons. As a result, more DA would be available in the extracellular space such that inhibition of the DA transporter by low doses of cocaine could result in increased cocaine reinforcement. Higher doses of cocaine result in increased extracellular DA levels to such an extent that, despite nAChR blockade, they are able to induce cocaine reinforcement.

Similar to what is observed in mice with genetic or pharmacological inactivation of nAChRs, the place preference induced by a low dose of cocaine was inhibited by chronic-intermittent administration of nicotine. Chronic and subchronic pretreatment with nicotine can result in either sensitization or tolerance to a nico- tine challenge, depending on the dose and treatment regimen of nicotine, as well as the pharmacological effect considered (Benwell and Balfour 1992; Benwell et al. 1994). Neurochemical studies in vitro have shown long-term inactivation of $\mathrm{nAChR}$-mediated DA release following exposure to micromolar nicotine concentrations (Rowell and Duggan 1998). The data reported here suggest that the mechanism underlying the effect of chronic-intermittent nicotine administration (0.7 $\mathrm{mg} / \mathrm{kg}$ ) on cocaine-related behaviors may be inactivation of nAChRs. Pretreatment with this dose of nicotine results in a similar effect on cocaine place preference to either administration of the nicotinic antagonist mecamylamine or knock out of the high affinity $\mathrm{nAChR}$. This treatment results in tolerance to the locomotor depressant effect of nicotine, and $\mathrm{C} 57 \mathrm{Bl} / 6$ mice do not develop locomotor sensitization under this drug regimen (unpublished observations). Although one injection of nicotine a day is not identical to the pattern of nicotine ingestion through smoking, the chronicintermittent nature of the treatment might be expected to have similar effects on desensitization and inactivation of nAChRs (Changeux et al. 1998). Indeed, chronic infusion of nicotine or mecamylamine in the mouse (Pauly et al. 1996), twice a day injections of nicotine in rat (Flores et al. 1997; Ulrich et al. 1997), and smoking in humans (Benwell et al. 1988; Breese et al. 1997) can all induce upregulation of nicotine binding sites, perhaps implying that inactivation of nAChRs might be the mechanism underlying this increase in nicotinebinding sites.

In contrast to cocaine, we saw no difference in morphine place preference in mice lacking the high affinity receptor for nicotine. One possibility for the difference seen between cocaine and morphine place preference is that cocaine exerts its reinforcing effects at least in part through direct effects on DA reuptake. In contrast, opiates are likely to work through actions on many brain areas, and in part by direct inhibition of the GABAergic output neurons in the Nac, which are the targets of the DA neurons (Koob and Nestler 1997). Thus, alteration of nicotinic modulation of the DA system might have a 


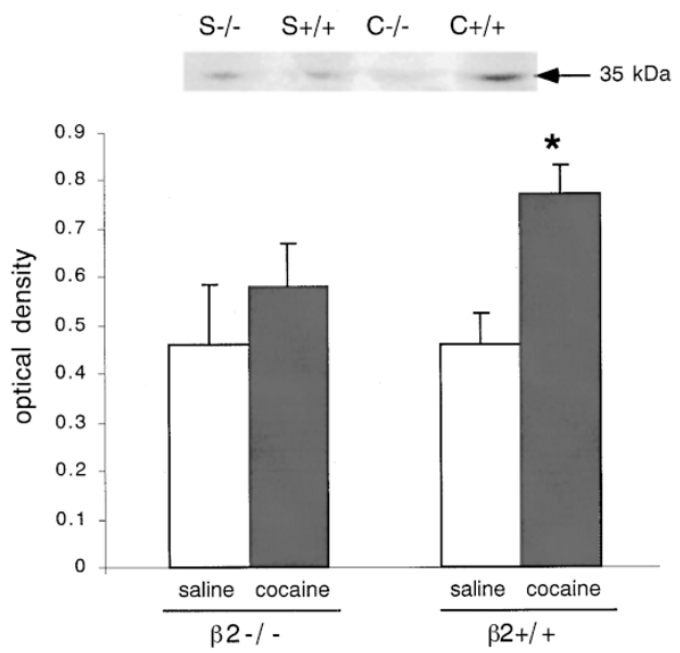

b

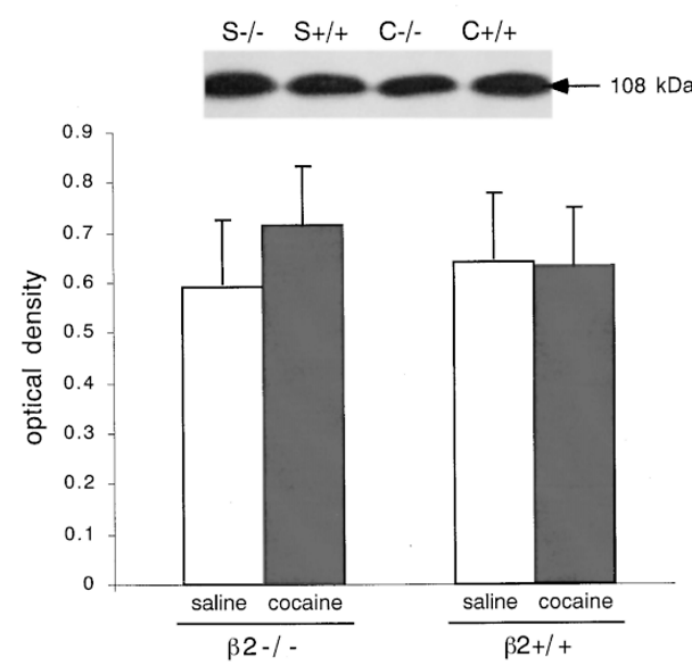

favor cocaine reinforcement; whereas, inactivation of $n A C h R s$ decreases cocaine reinforcement. These results are consistent with the hypothesis that one of the functions of acetylcholine acting through high affinity $n A C h R s$ in brain is to provide a level of tonic regulation of the DA system. In addition, the current data also suggest that cholinergic agonists and antagonists could be used to alter the efficacy of cocaine in drug abusers. Recent studies in humans have shown that mecamylamine can reduce cue-induced craving for cocaine (Reid et al. 1999). Treatment with nicotinic antagonists might, therefore, decrease the rewarding efficacy of cocaine in patients attempting to stop using cocaine, and could be of use in a cessation program.

\section{ACKNOWLEDGMENTS}

The authors thank Diann Stedman, Li Xu and Feng-Pei Chen for expert technical assistance. Drs. M. Zoli, M. Epping-Jordan, S. L. King, and E. J. Nestler are thanked for critical reading of the manuscript and helpful conversations about the work. This work was supported by Grants DA10455, DA00167, DA84733, and DA07290 from the National Institutes of Health and by The Christiane Brooks Johnson Foundation, a NARSAD grant to T.P.G. and R37-MH-14092 to R.H.R.

\section{REFERENCES}

Benwell ME, Balfour DJ, Anderson JM (1988): Evidence that tobacco smoking increases the density of (-)-[3H]nicotine binding sites in human brain. $J$ Neurochem 50(4):1243-1247

Benwell ME, Balfour DJ (1992): The effects of acute and repeated nicotine treatment on nucleus accumbens dopamine and locomotor activity. Br J Pharmacol 105(4):849-856

Figure 9. Induction of chronic fras by chronic intermittent nAChR. Cocaine was injected once a day for 7 days, and animals were sacrificed on day 8. a) Extracts from dorsal striatal punches were analyzed for fra-like immunoreactivity by Western Blotting. A representative blot is shown, and quantitation of autoradiograms is summarized graphically. ${ }^{*}, p<$ $.005 \beta 2+/+$ saline vs. cocaine treatment. b) GluR1 immunoreactivity following chronic intermittent cocaine treatment in animals lacking the high affinity nAChR. A representative blot is shown, and quantitation of autoradiograms is summarized graphically. GluR1 was considered to be an internal standard, because no change in GluR1 immunoreactivity has been seen in dorsal striatum following cocaine treatment. $\beta 2+/+$ : wild type mice; $\beta 2-/-$ : knock out mice; saline: 7 day saline treatment; cocaine: 7 day treatment with cocaine $(20 \mathrm{mg} / \mathrm{kg})$.

greater effect on the processes affected by cocaine, rather than the downstream processes affected by opiates.

In conclusion, the present results show that co-activation of $\mathrm{nAChR}$ - and cocaine-dependent mechanisms
Benwell ME, Balfour DJ, Khadra LF (1994): Studies on the influence of nicotine infusions on mesolimbic dopamine and locomotor responses to nicotine. Clin Invest 72(3):233-239

Breese CR, Marks MJ, Logel J, Adams CE, Sullivan B, Collins AC, Leonard S (1997): Effect of smoking history on [3H]nicotine binding in human postmortem brain. J Pharmacol Exp Ther 282(1):7-13

Calcagnetti DJ, Schechter MD (1993): Extinction of cocaineinduced place approach in rats: A validation of the "biased" conditioning procedure. Brain Res Bull 30(56):695-700

Changeux JP, Bertrand D, Corringer PJ, Dehaene S, Edelstein S, Lena C, Lenovere N, Marubio L, Picciotto M, Zoli M (1998): Brain nicotinic receptors-Structure and regulation, role in learning and reinforcement. Brain Res Rev 26(2-3):198-216

Clarke PBS, Pert A (1985): Autoradiographic evidence for nicotine receptors in nigrostriatal and mesolimbic dopaminergic neurons. Brain Res 348:355-348

Corrigall WA, Franklin KB, Coen KM, Clarke PB (1992): The 
mesolimbic dopaminergic system is implicated in the reinforcing effects of nicotine. Psychopharmacology 107(2-3):285-289

Corrigall WA, Coen KM, Adamson KL (1994): Self-administered nicotine activates the mesolimbic dopamine system through the ventral tegmental area. Brain Res 653(1-2):278-284

Dani JA, Heinemann S (1996): Molecular and cellular aspects of nicotine abuse. Neuron 16(5):905-908

Di Chiara G, Morelli M, Consolo S (1994): Modulatory functions of neurotransmitters in the striatum: ACh/ dopamine/NMDA interactions. Trends Neurosci 17(6):228-233

Epping-Jordan MP, Picciotto MR, Changeux JP, Pich EM (1999): Assessment of nicotinic acetylcholine receptor subunit contributions to nicotine self-administration in mutant mice. Psychopharmacology 147(1):25-26

Fitzgerald LW, Ortiz J, Hamedani AG, Nestler EJ (1996): Drugs of abuse and stress increase the expression of GluR1 and NMDAR1 glutamate receptor subunits in the rat ventral tegmental area: Common adaptations among cross-sensitizing agents. J Neurosci 16(1):274282

Flores CM, Davila-Garcia MI, Ulrich YM, Kellar KJ (1997): Differential regulation of neuronal nicotinic receptor binding sites following chronic nicotine administration. J Neurochem 69(5):2216-2219

Ghasemzadeh MB, Nelson LC, Lu XY, Kalivas PW (1999): Neuroadaptations in ionotropic and metabotropic glutamate receptor $\mathrm{mRNA}$ produced by cocaine treatment. J Neurochem 72(1):157-165

Grady S, Marks MJ, Wonnacott S, Collins AC (1992): Characterization of nicotinic receptor-mediated $[3 \mathrm{H}]$ dopamine release from synaptosomes prepared from mouse striatum. J Neurochem 59(3):848-856

Grenhoff J, Aston-Jones G, Svensson TH (1986): Nicotinic effects on the firing pattern of midbrain dopamine neurons. Acta Physiol Scand 128:351-358

Hadfield MG, Milio C (1992): Cocaine and regional brain monoamines in mice. Pharmacol Biochem Behav 43(2):395-403

Hadfield MG (1995): Cocaine. Selective regional effects on central monoamines. Mol Neurobiol 11(1-3):47-53

Haikala H, Ahtee L (1988): Antagonism of the nicotineinduced changes of the striatal dopamine metabolism in mice by mecamylamine and pempidine. Naunyn Schmiedebergs Arch Pharmacol 338(2):169-173

Hiroi N, Brown JR, Haile CN, Ye H, Greenberg ME, Nestler EJ (1997): FosB mutant mice: Loss of chronic cocaine induction of Fos-related proteins and heightened sensitivity to cocaine's psychomotor and rewarding effects. Proc Natl Acad Sci USA 94(19):10397-10402

Hiroi N, Nestler EJ (1998): Nuclear memory: Gene transcription and behavior. Adv Pharmacol 42:1037-1041

Hope B, Kosofsky B, Hyman SE, Nestler EJ (1992): Regulation of immediate early gene expression and AP-1 binding in the rat nucleus accumbens by chronic cocaine. Proc Natl Acad Sci USA 89(13):5764-5768

Horger BA, Giles MK, Schenk S (1992): Pre-exposure to amphetamine and nicotine predisposes rats to self- administer a low dose of cocaine. Psychopharmacology 107(2-3):271-276

Kelz MB, Chen J, Carlezon WA, Whisler K, Gilden L, Beckman A, Steffen C, Zheng Y-J, Marotti L, Self DW, Tkatch T, Baranauskas G, Surmeier DJ, Neve RL, Duman RS, Picciotto MR, Nestler EJ (1999): Expression of the transcription factor Delta FosB in the brain controls sensitivity to cocaine. Nature 401:272-276

Koob GF (1992): Neural mechanisms of drug reinforcement. Ann NY Acad Sci 654:171-191

Koob GF, Nestler EJ (1997): The neurobiology of drug addiction. J Neuropsychiat Clin Neurosci 9(3):482-497

Li X, Rainnie DG, McCarley RW, Greene RW (1998): Presynaptic nicotinic receptors facilitate monoaminergic transmission. J Neurosci 18(5):1904-1912

Lichtensteiger W, Hefti F, Felix D, Huwyler T, Melamed E, Schlumpf M (1982): Stimulation of nigrostriatal dopamine neurones by nicotine. Neuropharmacology 21(10): 963-968

Lowry OH, Rosebrough JJ, Farr AL, Randall RJ (1957): Protein measurement with the folin reagent. J Biol Chem 193:265-275

Marks M, Campbell S, Romm E, Collins A (1991): Genotype influences the development of tolerance to nicotine in the mouse. J Pharmacol Exp Ther 259(1):392-402

Marks MJ, Grady SR, Collins AC (1993): Downregulation of nicotinic receptor function after chronic nicotine infusion. J Pharmacol Exp Ther 266(3):1268-1276

Mereu G, Yoon KW, Boi V, Gessa GL, Naes L, Westfall TC (1987): Preferential stimulation of ventral tegmental area dopaminergic neurons by nicotine. Eur J Pharmacol 141(3):395-399

Mihailescu S, Palomerorivero M, Meadehuerta P, Mazaflores A, Druckercolin R (1998): Effects of nicotine and mecamylamine on rat dorsal raphe neurons. Eur J Pharmacol 360(1):31-36

Morency MA, Beninger RJ (1986): Dopaminergic substrates of cocaine-induced place preference conditioning. Brain Res 399:33-41

Nakamura S, Goshima Y, Yue JL, Miyamae T, Misu Y (1992): Transmitter-like 3,4-dihydroxyphenylalanine is tonically released by nicotine in striata of conscious rats. Eur J Pharmacol 222(1):75-80

Nisell M, Nomikos GG, Svensson TH (1994): Infusion of nicotine in the ventral tegmental area or the nucleus accumbens of the rat differentially affects accumbal dopamine release. Pharmacol Toxicol 75(6):348-352

Panagis G, Kastellakis A, Spyraki C, Nomikos G (2000): Effects of methyllycaconitine (MLA), an alpha7 nicotinic receptor antagonist, on nicotine- and cocaineinduced potentiation of brain stimulation reward. Psychopharmacology 149(4):388-396

Pauly JR, Marks MJ, Robinson SF, Van de Kamp JL, Collins AC (1996): Chronic nicotine and mecamylamine treatment increase brain nicotinic receptor binding without changing $\alpha 4$ or $\beta 2$ mRNA levels. J Pharmacol Exp Ther 278:361-369

Picciotto MR, Zoli M, Léna C, Bessis A, Lallemand Y, Le Novère $N$, Vincent $P$, Merlo-Pich $E$, Brulet $P$, Changeux J-P (1995): Abnormal avoidance learning in mice lacking 
functional high-affinity nicotine receptor in the brain. Nature 374:65-67

Picciotto MR, Zoli M, Zachariou V, Changeux J-P (1997): Contribution of nicotinic acetylcholine receptors containing the $\beta 2$ subunit to the behavioral effects of nicotine. Biochem Soc Trans 25:824-829

Picciotto MR (1998): Common aspects of the action of nicotine and other drugs of abuse. Drug Alc Depend 51(12):165-172

Picciotto MR, Zoli M, Rimondini R, Léna C, Marubio LM, Merlo Pich E, Fuxe K, Changeux JP (1998): Acetylcholine receptors containing the beta-2 subunit are involved in the reinforcing properties of nicotine. Nature 391:173-177

Pontieri FE, Tanda G, Orzi F, Di Chiara G (1996): Effects of nicotine on the nucleus accumbens and similarity to those of addictive drugs. Nature 382(6588):255-257

Reid MS, Mickalian JD, Delucchi KL, Hall SM, Berger SP (1998): An acute dose of nicotine enhances cue-induced cocaine craving. Drug Alc Depend 49(2):95-104

Reid MS, Mickalian JD, Delucchi KL, Berger SP (1999): A nicotine antagonist, mecamylamine, reduces cue-induced cocaine craving in cocaine-dependent subjects. Neuropsychopharmacology 20(3):297-307

Rocha BA, Fumagalli F, Gainetdinov RR, Jones SR, Ator R, Giros B, Miller GW, Caron MG (1998): Cocaine self- administration in dopamine-transporter knockout mice. Nature Neurosci 1(2):132-137

Rowell PP, Duggan DS (1998): Long-lasting inactivation of nicotinic receptor function in vitro by treatment with high concentrations of nicotine. Neuropharmacology 37(1):103-111

Schechter MD, Calcagnetti DJ (1993): Trends in place preference conditioning with a cross-indexed bibliography; 1957-1991. Neurosci Biobehav Rev 17(1):21-41

Schechter MD, Calcagnetti DJ (1998): Continued trends in the conditioned place preference literature from 1992 to 1996, inclusive, with a cross-indexed bibliography. Neurosci Biobehav Rev 22(6):827-846

Stolerman IP, Jarvis MJ (1995): The scientific case that nicotine is addictive. Psychopharmacology 117:2-10

Ulrich YM, Hargreaves KM, Flores CM (1997): A comparison of multiple injections versus continuous infusion of nicotine for producing up-regulation of neuronal [3H]epibatidine binding sites. Neuropharmacology 36(8): 1119-1125

Zachariou V, Parikh K, Picciotto MR (1999): Centrally administered galanin blocks morphine place preference in the mouse. Brain Res 831(1-2):33-42

Zoli M, Léna C, Picciotto MR, Changeux J-P (1998): Identification of four classes of brain nicotinic receptors using $\beta 2$-subunit mutant mice. J Neurosci 18:4461-4472 